\title{
The Fontan circulation: evolution of a concept
}

\author{
Zdenek Slavik \\ Department of Paediatrics, Royal Brompton Hospital, Royal Brompton \& Harefield NHS Trust, London, United Kingdom
}

Slavik Z. The Fontan circulation: evolution of a concept. Cor Vasa 2009;51(6):410-414.

The Fontan circulation is a specific haemodynamic concept developed and modified over the past 50 years to treat paediatric patients with complex congenital heart defects. The common denominator for these defects is usually a single dominant ventricle supporting both systemic and pulmonary circulation together with cyanosis since birth. Two main palliative cardiac surgical procedures (bidirectional superior cavopulmonary and total cavopulmonary anastomosis) are currently used to establish the Fontan circulation. Refinement of surgical techniques and improved understanding of perioperative and postoperative complications led to improvement in the survival of children and adults with complex congenital heart defects.

Key words: Fontan circulation - Superior bidirectional cavopulmonary anastomosis - Total cavopulmonary anastomosis - Complex heart defects

Slavik Z. Fontanova cirkulace: vývoj koncepce. Cor Vasa 2009;51(6):410-414.

Fontanova cirkulace je specifická hemodynamická koncepce vyvinutá a modifikovaná za posledních padesát let k léčbě dětských pacientů s komplexními vrozenými srdečními vadami. Společným jmenovatelem těchto vad je obvykle jedna dominantní srdeční komora podporující jak systémovou, tak i plicní cirkulaci společně s cyanózou od narození. Dnes se k vytvoření Fontanovy cirkulace uživají především dva paliativní kardiochirurgické výkony (horní bidirekční kavopulmonální a totální kavopulmonální anastomózu). Zlepšení chirurgických postupů a lepší porozumění operačním a pooperačním komplikacím vedlo ke zlepšenému přežití dětí a dospělých s komplexními srdečními vadami.

Klíčová slova: Cyanóza - Horní bidirekční kavopulmonální anastomóza - Totální kavopulmonální anastomóza - Komplexní srdeční vady

Address: Dr. Zdenek Slavik, MD (UK), FRCPCH, Royal Brompton Hospital, Sydney Street, London SW3 6NP, United Kingdom, e-mail: zslavik@hotmail.com

The first publication of the Fontan operation in 1971 followed previous experimental and clinical attempts at various palliative surgical procedures for patients born with complex congenital heart defects. ${ }^{(1-4)}$ A common feature of these complex congenital heart defects is often single dominant ventricle supporting both pulmonary and systemic circulation ultimately connected in series as opposed to their parallel arrangement in normal cardiovascular anatomy and physiology. Another common denominator is cyanosis caused by intracardiac mixing of systemic and pulmonary venous return together with reduced pulmonary blood flow in the majority of these patients.

Patients with hypoplastic left heart syndrome form a subgroup where palliative surgical algorithm includes systemic-to-pulmonary or right ventricle-to-pulmonary arterial shunt as part of their initial treatment strategy (stage I of Norwood operation). Up to $93 \%$ of the remaining patients with complex congenital heart defects (Table 1) benefiting from palliative cardiac surgical treatment fall broadly into two groups. ${ }^{(5,6)}$ Patients with initially reduced pulmonary blood flow have this increased by insertion of systemic-to-pulmonary arterial shunt, currently fashioned mostly as modified Blalock-Taussig shunt using interposition of Gore-Tex or other vascular graft between the subclavian artery and corresponding branch pulmonary artery. A smaller group of patients will have central cyanosis despite increased pulmonary blood flow and signs of congestive heart failure. Their first palliative surgical treatment usually involves pulmonary arterial banding. The remaining $7 \%$ of the patients will have a balanced ratio between pulmonary and systemic blood flow due to the variable degree of obstruction between the heart and pulmonary arteries where early palliation is not required. 
Table 1 Congenital heart defects where the Fontan circulation is used

- Pulmonary atresia with intact inter-ventricular septum (40\% with severe right ventricular hypoplasia)

- Tricuspid valve absence or atresia

- Double inlet left or right ventricle

- Hypoplastic left heart syndrome

- Complex defects with left or right isomerism

\section{Ideal palliation and bidirectional superior cavopulmonary anastomosis}

Ideal subsequent surgical palliation should provide controlled pulmonary blood flow allowing adequate tissue oxygenation and normal psychosomatic development, it should prevent damage to the pulmonary circulation and systemic ventricle, and be the final palliation or its part. Clinical introduction of bidirectional superior cavopulmonary anastomosis (BCPA), despite its later publication, preceded the introduction of Fontan operation in an attempt to redirect systemic venous return to pulmonary arteries bypassing the right ventricle in the quest for such an ideal palliation. ${ }^{(7)}$ BCPA is currently accepted second stage palliation in the majority of patients with complex congenital heart defects. ${ }^{(8)}$ There are, however, several important issues related to this surgical treatment that warrant closer attention.

The lowest age when BCPA can be safely performed remains controversial. It was shown that BCPA is a feasible palliation in selected patients even below 2 months of age. ${ }^{(9)}$ However, the postoperative care in such patients is particularly demanding requiring inhaled nitric oxide and/or negative pressure ventilation to successfully overcome the early postoperative period. A surgical approach through lateral thoracotomy avoiding the use of cardiopulmonary bypass, where possible, is particularly appealing in these patients. Medium-term pulmonary arterial growth is uncertain after BCPA at such a young age when it is the only source of pulmonary blood flow. ${ }^{(10)}$ The currently accepted safe early age for BCPA is between 4-6 months. ${ }^{(11,12)}$

The role of an additional source of pulmonary blood flow (stenotic native pulmonary valve, banded pulmonary artery, systemic-to-pulmonary artery shunt) following BCPA has been extensively studied. ${ }^{(11-14)}$ It became obvious that a single, restrictive additional source of pulmonary blood flow is not only well tolerated leading to shorter length of ventilation postoperatively ${ }^{(13)}$ but it also conveys several practical benefits. It contributes to better medium-term growth of the pulmonary artery contralateral to $\mathrm{BCPA}^{(10)}$ and limits an early onset of intra-pulmonary shunting with ensuing clinically significant cyanosis - see below. ${ }^{(15)}$

Pulmonary arterio-venous malformations develop in patients with pulmonary circulation deprived of hepatic effluent (after BCPA as the only source of pulmonary blood flow) or in patients with severely compromised liver function (i.e., patients with advanced hepatic cirrhosis hepatopulmonary syndrome). ${ }^{(16)}$ The presence of an additional source of pulmonary blood flow after BCPA should therefore eliminate or limit the extent of pulmonary arterio-venous malformations. We performed radionuclide lung perfusion scan using technetium-labelled albumin particles to assess the extent of intrapulmonary shunting in patients with surgically corrected congenital heart defects and biventricular circulation (control group) and in patients with univentricular hearts following BCPA with or without an additional source of pulmonary blood flow. ${ }^{(15)}$ Although patients with BCPA and an additional source of pulmonary blood flow had higher volume of intrapulmonary shunt (mean 12\%) than the control group with physiological shunt (mean $5 \% ; p=0.01$ ), patients with BCPA as the only source of pulmonary blood had markedly increased intrapulmonary shunt (mean 35\%, $p<0.001$ when compared with control group). Clinical implications of these findings are far reaching. Progressive cyanosis in the short-term and medium-term follow-up limits the use of BCPA as the final palliation in the majority of such patients. An additional source of pulmonary blood flow after BCPA thus at least partly alleviates progression of cyanosis and allows for long-term palliation in selected patients. ${ }^{(17)}$

\section{Total cavopulomonary connection}

The timing and type of final palliation involving redirection of inferior vena caval blood into the pulmonary arteries (total cavopulmonary connection - TCPC, Figure 1) has

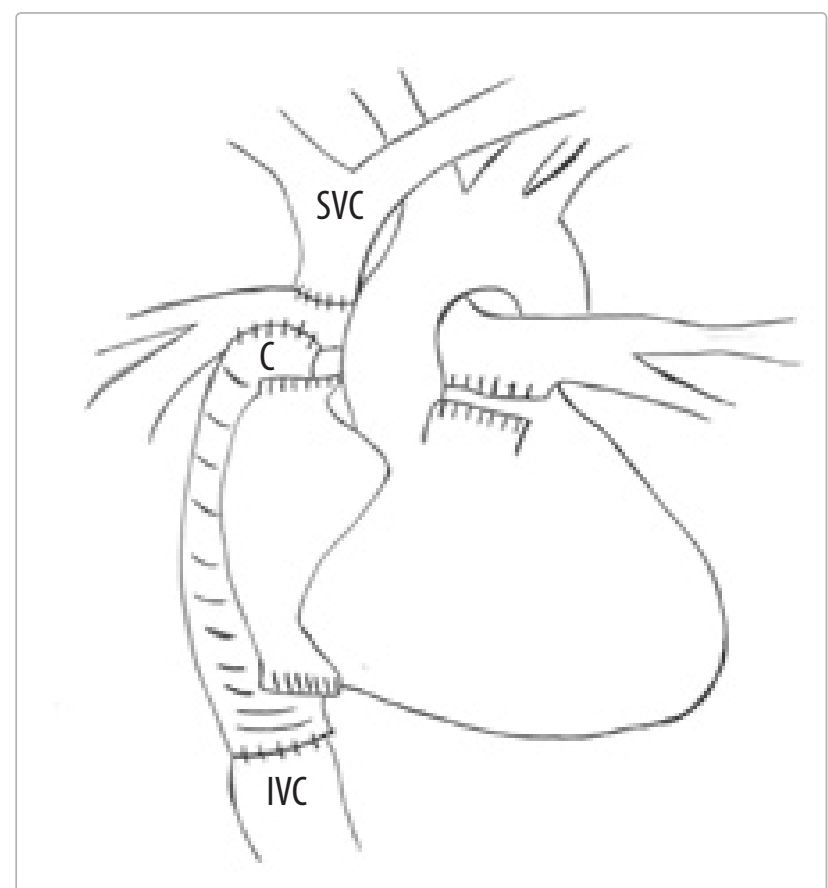

Figure 1 Diagram of total cavopulmonary connection showing direct anastomosis between the superior vena cava (SVC) and right pulmonary artery - bidirectional superior cavopulmonary anastomosis - and conduit (C) joining inferior vena cava (IVC) with right pulmonary artery 
undergone various modifications. Some institutions believe that completion of TCPC within 12-24 months after BCPA or even performance of a primary TCPC (single operation involving BCPA and TCPC) provides the best protection of the single ventricle against chronic volume overload and later failure. ${ }^{(18,19)}$ This notion is contradicted by experience of others ${ }^{(5,20)}$ who achieved remarkable long-term results with a staged approach and completion of TCPC later than 24 months after BCPA. Diastolic myocardial dysfunction and increased systemic vascular resistance are common early after BCPA or TCPC. ${ }^{(8,21)}$ Evidence exists for the benefit of BCPA performed separately from TCPC. This benefit relates to better adjustment of myocardial diastolic function and systemic vascular resistance before TCPC is carried out. ${ }^{(8)}$ Whether this adjustment translates into significant clinical improvement of long-term mortality and morbidity following TCPC is to be ascertained. . $^{(5,18,20)}$

\section{Postoperative management and complications}

\section{Bidirectional superior cavopulmonary anastomosis}

Early postoperative management of patients undergoing BCPA can be challenging. Nursing in head-up position is a simple measure ensuring enhanced systemic venous return through the superior vena cava (SVC) and reducing SVC syndrome. Relative hypoventilation with increased systemic arterial $\mathrm{PCO}_{2}(6-8 \mathrm{kPa})$ improves systemic (cerebral) oxygenation through lower cerebral vascular resistance and increased SVC and pulmonary blood flow. ${ }^{(22,23)}$ Early onset of spontaneous ventilation and extubation leading to intermittent negative intra-thoracic pressure improve SVC and pulmonary blood flow (a similar effect is achievable by negative pressure ventilation where necessary). A focus on lusitropic myocardial support and systemic vasodilatation (phosphodiesterase inhibitors milrinone or enoximone, ACE inhibitors) is beneficial given the adverse postoperative changes in myocardial function and systemic vascular resistance (increased ventricular wall to cavity ratio, diastolic dysfunction, increased systemic vascular resistance). ${ }^{(5,8,21)}$ Early removal of central venous catheters is desirable as a pro-coagulant tendency exists and the risk of thrombo-embolic complications is high. ${ }^{(24)}$ Insertion of trans-atrial catheters at the time of surgery has been advocated in these patients over the classic central venous approach.

Pleuropericardial and/or peritoneal fluid collections are common following BCPA. An altered pattern of flow in SVC, increased SVC pressure, and iatrogenic injury to the thoracic duct are considered the most frequent causes of these fluid collections with the fluid being serous or chylous in nature. ${ }^{(25,26)}$ Perioperative administration of intravenous enalapril followed by oral administration of captopril reduced the volume and duration of pleural drainage immediately after BCPA. ${ }^{(26)}$ We have shown that a strict diet containing fat only in the form of medium-chain triglycerides supplemented by intravenous infusion of octreotide (a somastostatin analogue) markedly cut down the volume and duration of pleural and peritoneal chylous drainage in some of the patients. ${ }^{(25)}$

Profound cyanosis in the early postoperative period may be caused by low pulmonary blood flow due to increased pulmonary vascular resistance and impaired lung diffusion capacity early after BCPA, and it strengthens the role of BCPA construction without the use of a cardiopulmonary bypass. ${ }^{(27)}$ Apart from the general recommendations for early postoperative management mentioned above, the use of pulmonary vasodilators (e.g., inhaled nitric oxide) and meticulous attention to fluid balance may prove useful in this situation. Early onset of intrapulmonary right-to-left shunting through arterio-venous malformations with marked systemic desaturation has been well described. ${ }^{(15,28)}$ Rapid opening of veno-venous collateral channels between the superior and inferior vena caval territory or inferior vena cava/azygos continuation of inferior vena cava and hepatic veins (in left isomerism following Kawashima modification of BCPA) have led to severe early postoperative cyanosis requiring closure of these channels through interventional cardiac catheterisation procedures. ${ }^{(29,30)}$

\section{Total cavopulmonary connection}

Details of early postoperative management are similar to the ones applicable to BCPA. Presence of atrioventricular synchrony is imperative for a successful outcome in all the patients. Sequential dual chamber pacing may be required through temporary or permanent epicardial leads as this mode of transvenous pacing is impossible given the newly constructed systemic venous pathways. Tachydysrhythmias (junctional ectopic or atrial ectopic) are poorly tolerated and need prompt diagnosis and treatment (correction of electrolyte dysbalance, control of body temperature including active cooling to normothermia or mild hypothermia 34-35 deg C - and/or intravenous administration of amiodarone to reduce intrinsic heart rate followed by atrial or sequential dual chamber pacing with rate above the intrinsic one). ${ }^{(31,32)}$

Early postoperative pleuropericardial and peritoneal fluid collection is common and the causes are mostly similar to those present after BCPA (see above). A complete heart block with a slow ventricular response or slow nodal rhythm lead to an increase in filling pressures and intrathoracic and/or peritoneal fluid collections. Early postoperative insertion of permanent pacemaker is justified as it leads to rapid resolution of fluid drainage (personal observation). Residual systemic-to-pulmonary shunt or collaterals are not tolerated and warrant aggressive transcatheter or surgical treatment. ${ }^{(33,34)}$

Severe cyanosis can occur in the early postoperative period caused by persistent intrapulmonary arterio-venous malformations related to previous BCPA (see above). ${ }^{(35)}$ High pulmonary arterial pressure/resistance may lead to significant right-to-left shunting across conduit fenestration 
Table 2 Survival of patients palliated by the Fontan circulation

\begin{tabular}{|c|c|c|c|c|c|c|}
\hline Author & Era & Patients No. & Survival 5 years & Survival 10 years & Survival 15 years & Survival 20 years \\
\hline \multirow[t]{2}{*}{ Cetta $^{(38)}$} & 1973-1986 & 500 & $70 \%$ & - & - & - \\
\hline & 1987-1992 & 339 & $81 \%$ & - & - & - \\
\hline Khairy ${ }^{(37)}$ & born $<1985$ & 261 & $94 \%$ & $90 \%$ & $87 \%$ & $83 \%$ \\
\hline Ono ${ }^{(20)}$ & 1984-1994 & 121 & $90 \%$ & - & - & $87 \%$ \\
\hline Hosein $^{(5)}$ & 1988-1994 & 406 & $90 \%$ & $86 \%$ & $82 \%$ & - \\
\hline
\end{tabular}

constructed, as a rule, or in selected patients considered high-risk candidates for TCPC completion. ${ }^{(5,20)}$ Treatment with inhaled nitric oxide and/or sildenafil has been used with some success. ${ }^{(5,36)}$

\section{Anticoagulation or antiplatelet medication following total cavopulmonary connection}

There is no consensus on the best prevention of thrombo-embolic complications early and late after TCPC. Protocols ranging from full anticoagulation using coumadin preparations (e.g., warfarin) through treatment with aspirin and/or clopidogrel to no medication have been used. ${ }^{(5,37)}$ Convincing evidence for the long-term benefit of anticoagulation or antiplatelet medication comes from the recently published study of Khairy et al. ${ }^{(37)}$ Their results show that thrombo-embolic complications were the cause of mortality in $7 \%$ of all the patients dying after TCPC. Lack of anticoagulation or antiplatelet treatment was an independent risk factor for death (HR 92; $p=0.0041)$.

\section{Long-term results of the Fontan circulation}

Given the heterogeneity of the patient population and changing surgical strategy over the last 40 years, it is difficult to compare published results on the long-term fate of patients palliated with the Fontan circulation. Nevertheless, the largest series of patients' results published to date comes from the Mayo Clinic. ${ }^{(38)}$ It is not surprising that results

Table 3 Patients' commandments required for successful use of the Fontan circulation

\begin{tabular}{ll}
\hline Choussat \& Fontan $1978^{(39)}$ & Hosein et al $2007^{(5)}$ \\
\hline Normal ventricular function & Normal ventricular function \\
\hline Pulmonary arterial pressure & Pulmonary arterial pressure \\
$<15 \mathrm{mmHg}$ & $<15 \mathrm{mmHg}$ \\
\hline Age $>4$ years & - \\
\hline Adequate pulmonary arterial size & - \\
\hline No pulmonary arterial distortion & - \\
\hline Low pulmonary vascular resistance & - \\
\hline Normal systemic venous drainage & - \\
\hline No atrioventricular valvar regurgitation & - \\
\hline Normal heart rhythm & - \\
\hline No right atrial enlargement & - \\
\hline
\end{tabular}

from an earlier era (1973-1986) improved in the later period (1987-1992) not only for early mortality (from $16 \%$ to $9 \% ; p=0.002$ ) but, also, for medium-term results (5-year survival from $73 \%$ to $81 \%$; $p=0.006)$. More recent data from other institutions show promising results of long-term follow-up with 20-year survival between $83 \%-87 \%$ (Table 2). ${ }^{(5,37)}$ These results have to be considered in light of the original 10 commandments related to individual patient's suitability for the Fontan circulation put forward by Choussat and Fontan in 1978 as the basis for successful palliation of complex congenital heart defects and the fact that they have been reduced to only 2 commandments in the current era (Table 3). ${ }^{(5,39)}$

\section{Conclusion}

The outlook of patients born with complex congenital heart defects has changed markedly over the past 40 years. The Fontan circulation has played a pivotal role in this success. The above results have to be considered against the almost $100 \%$ mortality the majority of the complex congenital heart defects carry when left untreated. It is also important to take into account that, despite best efforts, some of the patients, those with hypoplastic left heart syndrome in particular, will have a very poor long-term outcome despite numerous successful palliative procedures. ${ }^{(40)}$

\section{References}

1. Fontan F, Baudet E. Surgical repair of tricuspid atresia. Thorax 1971;26: 240-3.

2. Rodbard S, Wagner D. Bypassing the right ventricle. Proc Soc Exper Biol Med 1949;71:96-8.

3. Carlon C, Mondini P, De Marchi R. Surgical treatment of some cardiovascular diseases (a new surgical anastomosis). J Int Coll Surg 1951;16:1-3.

4. Glenn WWL. Circulatory bypass of the right side of the heart. IV. Shunt between superior vena cava and distal right pulmonary artery - report of clinical application. N Engl J Med 1958;259:117.

5. Hosein RBM, Clarke AJB, McGuirk SP, Griselli M, et al. Factors influencing early and late outcome following the Fontan procedure in the current era. The 'Two Commandments'? Eur J Cardiothorac Surg 2007;31:344-55.

6. Slavik Z, Franklin RC, Radley-Smith R. The real fate of pulmonary arteries after bidirectional superior cavopulmonary anastomosis; is there a need for concern? Cardiol Young 1999;9:6-10.

7. Azzolina G, Eufrate S, Pensa P. Tricuspid atresia: Experience in surgical management with a modified cavopulmonary anastomosis. Thorax 1972; 27:111-5.

8. Tanone Y, Sese A, Ueno Y, et al. Bidirectional Glenn procedure improves the mechanical efficiency of a total cavopulmonary connection in the high-risk Fontan candidates. Circulation 2001;103:2176-80.

9. Slavik Z, Lamb RK, Webber SA, et al. Bidirectional superior cavopulmonary anastomosis: how young is too young? Heart 1996;75:78-82. 
10. SlavikZ, Webber SA, Lamb RK, et al. Influence of bidirectional cavopulmonary anastomosis on pulmonary arterial growth. Am J Cardiol 1995;76: 1085-7.

11. Uemura H, Yagihara T, Kawashima Y, et al. Use of the bidirectional Glenn procedure in the presence of forward flow from the left ventricle to the pulmonary arteries. Circulation 1995;92:11228-32.

12. Caspi J, Pettit TW, Ferguson TB Jr, et al. Effect of controlled antegrade pulmonary blood flow on cardiac function after bidirectional cavopulmonary anastomosis. Ann Thorac Surg 2003;26:1917-21.

13. Webber SA, Horvath P, LeBlanc JG, et al. Influence of competitive pulmonary blood flow on the bidirectional superior cavopulmonary shunt. A multi-institutional study. Circulation 1995;92:II279-86.

14. Berdat PA, Belli E, Lacour-Gayet F, et al. Additional pulmonary blood flow has no adverse effect on outcome after bidirectional cavopulmonary anastomosis. Ann Thorac Surg 2005;79:29-36.

15. Vettukattil JJ, Slavik Z, Lamb RK, et al. Intrapulmonary arteriovenous shunting may be a universal phenomenon in patients with superior cavopulmonary anastomosis: a radionuclide study. Heart 2000;83:425-8.

16. Hopkins WE, Waggoner BA, Barzilai B. Frequency and significance of intrapulmonary right to left shunting in end stage hepatic disease. Am J Cardiol 1992;70:16-19.

17. Salmon AP, Sethia B, Silove ED, et al. Cavopulmonary anastomosis as long-term palliation for patients with tricuspid atresia. Eur J Cardiothorac Surg 1989;3:494-7.

18. Kostelka M, Hucin B, Tlaskal T, et al. Bidirectional Glenn followed by total cavopulmonary connection or primary total cavopulmonary connection? Eur J Cardiothorac Surg 1997;12:177-83.

19. Uemura H, Yagihara T, Kawahira Y, et al. Total cavopulmonary connection in children with body weight less than $10 \mathrm{~kg}$. Eur J Cardiothorac Surg 2000;17:543-9.

20. Ono $M$, Boething $D$, Goerler $H$, et al. Clinical outcome of patients 20 years after Fontan operation - effect of fenestration on late morbidity. Eur J Cardiothorac Surg 2006;30:923-9.

21. Selamet Tierney ES, Glickstein JS, Altmann K, et al. Bidirectional cavopulmonary anastomosis: impact on diastolic ventricular function indices. Pediatr Cardiol 2007;28;372-8.

22. Bradley SM, Simsic JM, Mulvihill DM. Hypoventilation improves oxygenation after bidirectional superior cavopulmonary connection. J Thorac Cardiovasc Surg 2003;126:1033-9.

23. Mott AR, Alomrani A, Tortoriello TA, et al. Changes in cerebral saturation in response to mechanical ventilation alterations in infants with bidirectional superior cavopulmonary connection. Pediatr Crit Care Med 2006;7:396-7.

24. Heying R, van Oeveren W, Wilhelm S, et al. Children undergoing cardiac surgery for complex cardiac defects show imbalance between pro- and anti-thrombotic activity. Crit Care 2006;10:R165.
25. Pratap U, Slavik Z, Ofoe VD, et al. Octreotide to treat postoperative chylothorax after cardiac operations in children. Ann Thorac Surg 2001;72: 1740-2.

26. Thompson LD, McElhinney DB, Culbertson CB, et al. Perioperative administration of angiotensin converting enzyme inhibitors decreases the severity and duration of pleural effusions following bidirectional cavopulmonary anastomosis. Cardiol Young 2001;11:195-200.

27. Tireli E, Ugurlucan M, Basaran M, et al. Extracardiac Fontan operation without cardiopulmonary bypass. J Cardiovasc Surg 2006;47:699-704.

28. Duncan BW, Desai S. Pulmonary arteriovenous malformations after cavopulmonary anastomosis. Ann Thorac Surg 2003;76:1759-66.

29. Stumper O, Wright JG, Sadiq M, De Giovanni JV. Late systemic desaturation after total cavopulmonary shunt operations. Br Heart J 1995;74:282-6.

30. Slavik Z, Lamb RK, Webber SA, et al. A rare cause of profound cyanosis after Kawashima modification of bidirectional cavopulmonary anastomosis. Ann Thorac Surg 1995;60:435-7.

31. Laird WP, Snyder CS, Kertesz NJ, et al. Use of intravenous amiodarone for post operative junctional ectopic tachycardia in children. Pediatr Cardiol 2003;24:133-7.

33. Hope S, Partridge J, Slavik Z. A novel use of an Amplatzer septal occluder. Heart 1999;81:672-3.

34. Lamberti JJ, Mainwaring RD, Spicer RL, et al. Factors influencing perioperative morbidity during palliation of the univentricular heart. Ann Thorac Surg 1995;60:S550-3.

35. Premsekar R, Monro JL, Salmon AP. Diagnosis, management, and pathophysiology of post-Fontan hypoxaemia secondary to Glenn shunt related pulmonary arteriovenous malformation. Heart 1999;82:528-30.

36. Bhate S, Rossiter-Thornton M, Cooper SG, et al. Use of sildenafil and nitric oxide in the management of hypoxemia owing to pulmonary arteriovenous fistulas after total cavopulmonary connection. J Thorac Cardiovasc Surg 2008;135:446-8.

37. Khairy P, Fernandes SM, Mayer JE Jr, et al. Long-term survival, modes of death, and predictors of mortality in patients with Fontan surgery. Circulation 2008;117:85-92.

38. Cetta F, Feldt RH, O'Leary PW, et al. Improved early morbidity and mortality after Fontan operation: the Mayo Clinic experience, 1987 to 1992. J Am Coll Cardiol 1996;28:480-6.

39. Choussat A, Fontan F, Besse P. Selection criteria for Fontan's procedure. In: Anderson RH, Shinebourne EA, eds. Pediatric Cardiology. Edinburgh: Churchill Livingstone, 1978:559-66.

40. Slavik Z, Skovranek J. Hypoplastic left heart syndrome - cui bono? Ces-slov Pediat 2007;62:37-9.

Received 5 February 2009

Revision accepted 27 May 2009 